Research Article

Journal of Extension Education

Vol. 31 No. 3, 2019

DOI:https://doi.org/10.26725/JEE.2019.3.31.6343-6348

\title{
Cultivation and Marketing Knowledge level of Areca nut Farmers in Andaman \& Nicobar Islands
}

\author{
B. L. Kasinath ${ }^{1}$, B.L. Meena ${ }^{2}$, Shailesh Kumar $^{3}$, S.V.Lal ${ }^{4}$, P. Kapoor ${ }^{5}$ and B. Gangaiah ${ }^{6}$
}

\begin{abstract}
Areca nut (Areca catechu $L$ ) also known as betel nut or supari is the second most important plantation crop of Andaman and Nicobar Islands (ANI) after coconut It has been observed that wide differences in productivity of areca nut exist among the farmers with in a village due to socio-economic status. A survey based study was conducted to understand the knowledge level of areca nut growers and link to productivity vis-a-vis socio-economic status. For this purpose, 120 areca nut farmers from four villages of Harinagar Panchayat were randomly selected. Data collected were analysed following standard statistical procedures. The results showed that $52.5 \%$ of areca nut growers had poor knowledge of cultivation and marketing. The study also revealed that about $45 \%$ growers had poor knowledge about selection of suitable site, soil and spacing requirement for plants. The analysis of socio-economic factors with knowledge level of farmers revealed that knowledge of respondents increased with the increase in their education and land holdings whereas it was negatively correlated with age and annual income. Further, the study also suggests that, educating the farmers through mass media, capacity building and demonstration will help them in learning/ a dopting new technologies, which in turn help them to increase their productivity level and farming income on sustainable basis.
\end{abstract}

Keywords: Knowledge; Areca nut; Productivity; Socio-Economics; Andaman \& Nicobar Islands

\section{INTRODUCTION}

Areca nut (Areca Catechu L.) is an important commercial plantation crop grown in India. The research and extension institutions recommend of improved production technologies to farmers for achieving higher returns, yet the growers are not following all the recommended technologies and their cultivation pattern vary from farmer to farmer according to their personal, psychological, socio-economical characteristics, availability of inputs for cultivation and avenues for marketing of areca nut. A study in Uttaranchal had showed that 73.60 per cent knowledge gap existed with respect to adoption of improved Agricultural practices (Chandra and Pandey, 2006). Hence, it was felt to analyse knowledge and adoption levels of

\footnotetext{
${ }^{1}$ Senior Scientist \& Head, ICAR-Krishi Vigyan Kendra, ${ }^{2-6}$ Subject matter specialist, ICAR-Central Island Agriculture Research Institute, Andaman and Nicobar Islands - 744201.
}

Received : 08-12-2019; Accepted : 03-03-2020 
recommended cultivation practices of areca nut growers; their economic performance in relation to their personal, psychological, socioeconomical characteristics and the problems faced by them. Keeping this in view the present study has been undertaken to study and ascertain knowledge level of farmers in the middle Andaman regarding areca nut cultivation and marketing and its relationship with farmers' socio economic characteristics.

\section{METHODOLOGY}

The study was conducted in the year 2017-18 in middle Andaman area of North and Middle Andaman district. Four villages under Harinagar Panchayat viz., Harinagar,Kamalapur,Pinakininagar and Jaipur representing major areca nut growing belt was selected for the study in consultation with local line departments. A total of 120 farmers were selected randomly for the study and data was collected using pre-tested structural schedule through personal interview method. The data were analyzed and tabulated using frequency and percentage.

The knowledge level of farmers was measured using three point scale on areca nut grower's knowledge about selection of suitable site/soil, selection of suitable varieties, spacing and proper method of land preparation, application of manure (FYM) and fertilisers, knowledge about pests and diseases, pesticides, fungicides and weedicides, waiting period \& pesticide residue. Knowledge was evaluated in terms poor knowledge, medium knowledge and good knowledge. Knowledge of individual farmer was calculated by adding the scores of 14 dimensions. In addition to this information on age and education was also collected and analysed during the study.

\section{FINDINGS AND DISCUSSION}

The knowledge adoption is a social process (Rogers, 2003) and the behaviour is influenced by many factors like social networks, personal circumstances, education and economic situations (Singh et al., 2011). In this study, the majority of respondents were in the age group of less than 60 years (38\%). It was observed that only 28 per cent of young (age $<35$ years) are engaged in areca nut cultivation. The education level of respondents showed that 46.66 per cent farmers are illiterate/ studied up to 8 th standard and only 33.33 per cent farmers studied up to secondary level. Only 20 per cent of them had completed the graduation.

Table-1 shows that in the present study it was found that 44.16 per cent respondents owned less than 1.0 ha while majority of farmers owned less than 1.0 ha area under areca nut cultivation. Areca nut crop contributes major proportion of income $(57.5 \%)$ of farmers out of their total annual income (more than 1.5 lakhs). The annual income (more than 2.0 lakhs) of the majority of farmers (46.66\%) are categorised in higher income group and areca nut cultivation contributes around 50 per cent of annual income of the farmers.

As shown in Table-2, knowledge levels of respondents were analysed considering 14 parameters. Majority of farmers were found to possess poor knowledge about site selection and suitable soil requirement for the 
Cultivation and Marketing Knowledge level of Areca nut Farmers in Andaman \& Nicobar Islands

Table.1

Socio Economic Profile of Areca nut Growers

\begin{tabular}{|c|c|c|c|c|}
\hline & & & & $(n=12 C$ \\
\hline SI. & & & Rest & dents \\
\hline No. & Protile Characters & Classification & Frequency & Percentage \\
\hline 1 & Age & Less than 35 years (Young) & 34 & 28.33333 \\
\hline & & 35 to 60 years (Middle) & 46 & 38.33333 \\
\hline & & Above 60 years(Old) & 40 & 33.33333 \\
\hline 2 & Education level & & & \\
\hline & & Illiterate/Less than VIII std & 56 & 46.66667 \\
\hline & & up to XII std. & 40 & 33.33333 \\
\hline & & Graduate \& Above & 24 & 20.00 \\
\hline 3 & Total Owned Area & Less than 1 ha & 53 & 44.16667 \\
\hline & & 1.0 ha to 2.0 ha & 35 & 29.16667 \\
\hline & & More than 2.0 ha & 32 & 26.66667 \\
\hline 4 & Area under Areca nut & Less than 1 ha & 83 & 69.16667 \\
\hline & & 1.0 ha to 2.0 ha & 21 & 17.5 \\
\hline & & More than $2.0 \mathrm{ha}$ & 16 & 13.33333 \\
\hline 5 & Total Annual income & Less than Rs 1.5 lakh (low) & 20 & 16.66667 \\
\hline & & Rs.1.5 to Rs 2.0 lakh (Medium) & 44 & 36.66667 \\
\hline & & More than Rs 2.0 lakh (High) & 56 & 46.66667 \\
\hline 6 & $\begin{array}{l}\text { Income from Arecanut } \\
\text { Cultivation }\end{array}$ & Less than Rs1.0 lakh (low) & 12 & 10.00 \\
\hline & & $\begin{array}{l}\text { Rs. } 1.0 \text { lakh to Rs } 1.5 \text { lakh } \\
\text { (Medium) }\end{array}$ & 39 & 32.5 \\
\hline & & More than Rs 1.5 lakh (High) & 69 & 57.5 \\
\hline
\end{tabular}

crop (43\%). This may be due to the fact that the farmers owning mostly hilly land and are forced to take up the cultivation irrespective of soil types.

For growing a successful crop, improved varieties play a vital role and the study shows that 46.66 per cent farmers do not have knowledge about availability of high yielding disease resistance varieties/ hybrids, which is very much essential to minimize the crop loss as well as reduces the cost of production through minimising the 
Table 2.

Knowledge level of Respondents about Basic Agricultural Practices

\begin{tabular}{|l|l|c|c|c|c|c|c|}
\hline \multirow{2}{*}{$\begin{array}{r}\text { SI. } \\
\text { No. }\end{array}$} & \multicolumn{1}{|c|}{ Cultivation Practices } & \multicolumn{2}{|c|}{$\begin{array}{c}\text { Poor } \\
\text { knowledge }\end{array}$} & $\begin{array}{c}\text { Medium } \\
\text { knowledge }\end{array}$ & \multicolumn{2}{c|}{$\begin{array}{c}\text { Good } \\
\text { knowledge }\end{array}$} \\
\cline { 3 - 8 } & & $\begin{array}{c}\text { Frequ } \\
\text { ency }\end{array}$ & $\begin{array}{c}\text { Percen } \\
\text { tage }\end{array}$ & $\begin{array}{c}\text { Frequ } \\
\text { ency }\end{array}$ & $\begin{array}{c}\text { Percen } \\
\text { tage }\end{array}$ & $\begin{array}{c}\text { Frequ } \\
\text { ency }\end{array}$ & $\begin{array}{c}\text { Percen } \\
\text { tage }\end{array}$ \\
\hline 1 & Selection of Suitable Site/Soil & 52 & 43.33 & 44 & 36.66 & 24 & 20 \\
\hline 2 & Selection of Suitable Varieties & 56 & 46.66 & 44 & 36.66 & 20 & 16.66 \\
\hline 3 & $\begin{array}{l}\text { Spacing and Proper Method } \\
\text { Land Preparation }\end{array}$ & 52 & 43.33 & 48 & 40 & 20 & 16.66 \\
\hline 4 & $\begin{array}{l}\text { Application of manure (FYM) } \\
\text { application \& Fertilisers }\end{array}$ & 68 & 56.66 & 32 & 26.66 & 20 & 16.66 \\
\hline 5 & $\begin{array}{l}\text { Knowledge about pests and } \\
\text { diseases }\end{array}$ & 64 & 53.33 & 32 & 26.66 & 24 & 20.00 \\
\hline 6 & $\begin{array}{l}\text { Knowledge about pesticides, } \\
\text { fungicides and weedicides }\end{array}$ & 68 & 56.66 & 32 & 26.66 & 20 & 16.66 \\
\hline 7 & $\begin{array}{l}\text { About waiting period knowledge } \\
\text { for pesticide residue }\end{array}$ & 76 & 63.33 & 24 & 20 & 20 & 16.66 \\
\hline 8 & Knowledge about Biological \\
control methods & 88 & 73.33 & 28 & 23.33 & 4 & 3.33 \\
\hline 9 & $\begin{array}{l}\text { Knowledge about use of organic } \\
\text { pesticides/ bio control methods }\end{array}$ & 71 & 59.16 & 28 & 23.33 & 21 & 17.5 \\
\hline 10 & $\begin{array}{l}\text { Knowledge about harvesting } \\
\text { index }\end{array}$ & 48 & 40 & 51 & 42.5 & 21 & 17.5 \\
\hline 11 & $\begin{array}{l}\text { Knowledge of post harvest } \\
\text { handling/packing }\end{array}$ & 56 & 46.66 & 32 & 26.66 & 32 & 26.66 \\
\hline 12 & Knowledge about grading & 52 & 43.33 & 44 & 36.66 & 24 & 20.00 \\
\hline 13 & Knowledge about marketing & 64 & 53.33 & 40 & 33.33 & 16 & 13.33 \\
\hline 14 & $\begin{array}{l}\text { Knowledge about marketing } \\
\text { costs }\end{array}$ & 72 & 60 & 32 & 26.66 & 16 & 13.33 \\
\hline & Mean & 63.35 & & 36.5 & & 20.14 & \\
\hline
\end{tabular}

requirement of plant protection chemicals, and for achieving desirable yields and income.

In the present study, it was observed that majority of farmers were not aware about application of manure and fertilizers application (56.66 \%), possessed poor knowledge about pest and diseases (53.33\%), and poor knowledge $(56.66 \%)$ on use of 
Cultivation and Marketing Knowledge level of Areca nut Farmers in Andaman \& Nicobar Islands

Table 3.

Overall classification of Knowledge level of respondents towards Basic Agricultural Practices

\begin{tabular}{|c|l|c|c|}
\hline \multirow{2}{*}{ SI. No. } & \multirow{2}{*}{ Knowledge level of respondents } & \multicolumn{2}{|c|}{ Classification } \\
\cline { 3 - 4 } & & Frequency & Percentage \\
\hline 1 & Poor Knowledge & 63 & 52.5 \\
\hline 2 & Medium Knowledge & 37 & 30.83333 \\
\hline 3 & Good Knowledge & 20 & 16.66667 \\
\hline & Total & 120 & 100.00 \\
\hline
\end{tabular}

pesticides/fungicides. This may be due to less pest and disease problems in areca nut crop in the Island, non-availability of plant protection chemicals and lack of awareness about pest and diseases as they are still dependent on agricultural department for supply of plant protection chemicals.

The data presented in Table- 3 shows the overall knowledge level of respondents towards basic areca nut cultivation practices. It was observed that 52.5 per cent of respondents possessed poor knowledge, about latest technologies/skills in areca nut cultivation. This may be mainly due to lower socio-economic status of the farmers. The adoption behaviour is influenced by many factors like their social networks, personal circumstances, education and economic situations (Singh et al., 2011). Thus there is need to increase the level of knowledge through awareness training/ demonstrations in order to achieve the desirable yield levels in areca nut cultivation on sustainable basis.

The knowledge level of respondents in different dimensions of areca nut cultivation were subjected to correlation analysis with their socio-economic parameters like land holdings, age, education and annual income as given in Table-4. The knowledge level about cultivation, marketing aspects of areca nut showed land holdings and education level showed positive correlation and on the

Table 4.

Correlation of Socio Economic Status with Knowledge level of respondents

\begin{tabular}{|c|l|c|}
\hline Sl. No. & \multicolumn{1}{|c|}{ Socio economic parameter } & Knowledge Correlation coefficient " $r$ " \\
\hline 1 & Total Owned Area & 0.9635341 \\
\hline 2 & Area under Areca nut & 0.9439795 \\
\hline 3 & Total Annual income & -0.99756 \\
\hline 4 & Income from Areca nut & -0.988676 \\
\hline 5 & Age & -0.988676 \\
\hline 6 & Educational Level & 0.9927778 \\
\hline
\end{tabular}


other hand income and age were negatively correlated. It can be consumed that educated farmers are more motivated towards learning new innovations in farming.

\section{CONCLUSION}

The farmers in middle Andaman possessed poor to medium level of knowledge in areca nut cultivation practices. It was observed that farmers had poor knowledge in use of improved varieties for better productivity and returns and possessed medium knowledge level in nutrient, and have poor knowledge in plant protection and postharvest management aspects. This may be the reason for the lower productivity levels and lower annual income in Island farmers. Further it was found that due to lack of storage and subsidised transport facilities, they have been forced to sell their produce at local markets that too to middlemen. Effort should be made by developmental departments for establishment of FPOs and subsidized transport and storage facilities should be provided. In order to increase the productivity, effort should be made by the extension institutions in motivating and educating the farmers through mass media, capacity building programmes and demonstrations.

\section{REFERENCES}

Chandra, N. \& Pandey, D. (2006) Transfer of technology in hill agriculture. In Gupta, H.S., Srivastav, A.K. and Bhatt, J.C. (Eds) Sustainable production from Agricultural Watersheds in North West Himalaya. Vivekanand parvitiya Krishi Anusandan Sansthan,Almora,pp526-534.

Rogers, E. M. (2003). Diffusion of innovations. Free press. New York.

Singh, D. K., Gautam, U. S., Singh. S. R. K., \& Patle, N. K., (2011). Awareness of farmers related Crop Production technology in Sagar, Madhya Pradesh. Indian Journal of Extension Education. 47 (1\&2):113-116. 